\title{
Extra-Legal Legality: Orientalism and Biopolitics in a State of Exception
}

\author{
Igbinedion Obaretin*
}

School of Language, Literature, Music, and Visual Culture, King's College University of Aberdeen, AB24 3UBScotland, United Kingdom Corresponding Author: Igbinedion Obaretin, E-mail: i.obaretin14@aberdeen.ac.uk

\section{ARTICLE INFO}

\section{Article history}

Received: April 09, 2018

Accepted: June 17, 2018

Published: July 31, 2018

Volume: 6 Issue: 3

Conflicts of interest: None

Funding: None

\begin{abstract}
With recourse to the poetry of Guantanamo's detainees, this article describes the extra-legal legality that typifies the conception and activities of post-9/11 terror-suspect prison camps. It argues that the state of exception, which has become integral in the war on terror, is not a product of necessity, but a reflection of the interplay between biopolitics, biopower, and Orientalism in the post-9/11 era. By considering the ways in which Guantanamo detainees employ poetry to plead their innocence and exhibit their suffering body as political subjects and objects, this article pays careful attention to the aesthetics of Guantanamo poetry and how it reveals the poets' individual humanity against the fabric of the brutality and illegality packaged ironically as the 'war on terror'.
\end{abstract}

\author{
Keywords: \\ Orientalism, \\ Biopolitics, \\ Biopower, \\ State of Exception, \\ Homo Sacer (Bare Life) and \\ Aesthetics
}

\section{INTRODUCTION}

While the violence and misery of post-9/11 state terrorism is appalling, there is still another aspect of state response to terrorism that may be far less desirable than the dropping of bombs. This consists of extreme measures which are inconsistent with the principles, values, and legal framework of modern democracies - measures that negate 'the promised legal justice', 'the pattern inherited from the great catastrophe and the collective traumas of the twentieth century', which 'has become civilisation's most appropriate and most essential, most ultimate meaningful response to the violence that wounds it.' (Felman 3). Paramount among these measures are indiscriminate arrest, detention without trial, and torture of terrorism suspects.

The illicitness of the measures highlighted above brings to the fore several questions. First, how were these dehumanising acts experienced by the victims? How did the victims of extra-legal legality - Guantanamo detainees, for instance - employ poetry to plead their innocence and exhibit their suffering body as political subjects and objects, having been denied the right to trial and fair hearing? In what ways is the power of aesthetics demonstrated in the production and rendition of their literary works? Crucially, why were these illicit measures considered appropriate by the states or the agents of the states involved in their perpetration, even though these measures arguably represent the worst of human rights violations? To discuss these issues dialectically, I will engage in this article with a selection of poems written by Guantanamo detainees against a backdrop of Edward Said's Orientalism and Giorgio Agamben's State of Exception.

The state of exception, a legal theory proposed by Carl Schmitt and further developed by Giorgio Agamben, is similar to the state of emergency, except that it is based on the sovereign power of the state to transcend the rule of law in the interest of the public. Generally, states of emergency 'challenge the state's commitment to govern through law' (Ramraj 3-4). It is thus 'posited as a juridical problem', and the response to the situation of emergency is 'considered to be constituted by law - the emergency law (Farrell 26). On the other hand, the state of exception as posited by Agamben is 'constitutive of the juridical order' (Farrell 26). This is however a tentative description (or definition) to be critically examined later because this article seeks to establish the link between state of exception, biopolitics and post-9/11 Orientalism.

As Said puts it, Orientalism is 'a political vision of reality whose structure promoted the differences between the familiar (Europe, the West, "us") and the strange (the Orient, the East, “them")' (Said 43). Notably, the differ- 
ences Orientalism promotes are arguably similar to the differences associated with the biopolitics of exclusion, whether it relates to the 'immigrant other' or the 'oriental other'. What then is biopolitics? How is it interlaced with the discourse of otherness? How is it situated in the very heart of the state of exception? Biopolitics, as the name suggests, is an intersectional domain between biology and politics (Stella and Nartova 28). Though the coinage of the term 'biopolitics' is widely attributed to a Swedish political scientist and politician, Rudolf Kjellen, who equally coined the word 'geopolitics', it was actually first used by G. W. Harris in an article published in The New Age on the $28^{\text {th }}$ of December 1911 (Turda 112). The term was also used by the Nazis, and more specifically, in the 1933 speech of Hans Conrad Julius Reiter - an infamous German physician, convicted of war crimes for his unethical medical experiment at the Buchenwald concentration camp in Nazi Germany (Liesen and Walsh 3; Panush et al. 693-694). Generally, the Nazis used the term biopolitics to refer to their concept of national and racial policy, which were indisputably biologically based (Liesen and Walsh 2-15). This article will thus interrogate both the legality and necessity of state of exception, while focusing on the circumstances and experiences of Guantanamo detainees as portrayed in Guantanamo poetry.

Guantanamo poems are the poems authored by the detainees of Guantanamo Bay detention camp, who are mainly Arabs or speakers of Pashto. Though the poems were published in English, many Guantanamo poets composed their poems originally in Arabic or Pashto. Hundreds of Guantanamo poems, which are still being supressed by the military, may never be published, or seen by the public. The Pentagon considers Guantanamo poems as a significant risk to national security. Because the Pentagon also believes that their original versions written in Arabic or Pashto presents a higher security risk, the poems that have been released so far are in English translation (Falkoff 4-5). The Editor of Poems from Guantanamo, Marc Falkoff, explains the constraints associated with the translation of the poems and how these constraints impacted on the artistic quality of the English translation:

Because only linguists with secret-level security clearances are allowed to read our clients' communications (which are kept by court order in a secure facility in the Washington, D. C., area) it was impossible to invite experts to translate the poems for us. The translations that we have included..., therefore, cannot do justice to the subtlety and cadence of the originals (Falkoff 5).

While the Pentagon considers Guantanamo poems as a substantial security risk, the poems are certainly testimonies of extra-legal legality - testaments of torture and human rights violations carried out under the state of exception. Made available to the public as published works through the untiring efforts of so many lawyers, academics, law students, and human rights activists who committed themselves resolutely to ensuring that the rule of law is extended to Guantanamo (Trapp 7), Guantanamo poetry has thus been largely studied as 'an extension of the discourses of human rights and of political resistance.' (Trapp 7).

\section{THE AESTHETICS OF GUANTANAMO POETRY - INTERROGATING THE POST-9/11 STATE OF EXCEPTION}

In this article, the poems' aesthetics are to be considered. In other words, we are to consider the poems as literary works, which illuminate issues that are of paramount importance in contemporary terrorism discourse. For one thing, it is the aesthetic merits of the poems, which, to a great extent, make them important as they take us through the barriers of the prison walls and wires to expose covert or surreptitious state atrocities perpetrated in 'dark' rooms, where the news media cameras were for many years disappointingly dysfunctional. Indeed, the poems' aesthetics will provide us with a better idea of the poets as political subjects and objects, and of the pains and misery of subjugation. This is very important as Guantanamo poetry has so far received very negligible attention from literary critics. In fact, it has not been of any significant gravitational pull, except for its employment in the discourses of political resistance and human rights violations (Trapp 7-8). Again, studying Guantanamo poems as literary works will enhance our ability to sympathise and empathise with the poets/detainees as they testify aesthetically of their torture and suffering. For the poems' tropes exhibit the suffering bodies of the political subjects, not only as objects to be observed, but to be identified with. Thus, the poems' aesthetics help to reveal the poets' individual humanity against the fabric of the brutality and illegality packaged ironically as the 'war on terror'.

While Guantanamo's poets were not certain if their poems would ever be published due to censorship, they use their poems for self-exaltation, and this helps them to overcome the depressing conditions characteristic of their incarceration, torture, and humiliation. Quite often they eulogise their patience, bravery, and resilience. They also contrast their innocence and resilience with the cruelty and cowardly brutality of the United States. In a couplet, entitled 'Cup Poem 2', Abdurraheem exalts himself epigrammatically as a brave man:

Handcuffs befit brave young men

Bangles are for spinsters or pretty young ladies (Falkoff 35)

The tone here is one of defiance. It goes a long way to accentuate the ways in which poetry helps the detainees to rise above humiliation.

Again, the relationship between 'handcuffs' and 'bangles' is rather complex, and in these lines, it carries an overtone of certain form of masculinity. While both handcuffs and bangles belong to the wrists, bangles connote elegance, grace, and femininity. On the other hand, handcuffs - as restraint devices - connote conflict with the law - the forces of cohesion or oppression - and crucially, their apparently assertive association with masculinity in these lines is indicative of the poet's construction of gender roles in societal struggle. In other words, beauty and elegance are in the sphere of femininity, while resistance is the function of masculinity. The self-exaltation implicit in the couplet is that the poet's incarceration is not indicative of weakness, but a reflection of his acceptance and commitment to what he perceives as his gender role. The self-exaltation is achieved through an 
ingenious employment of conceit, which decriminalises handcuffs through their association with gender roles. The employment of logic and conceit in Guantanamo poetry is arguably reminiscent of metaphysical poetry, characterised with inventive use of conceit and logic as opposed to the depiction of emotions and emphasis on the lyrical quality of verse (Hoyles 39; Reid 2; Greene et al. 290).

Poems were also letters of exaltation that the detainees write to one another (Mullins 220). Abdulla Noaimi, for instance, composed his poems, 'My Heart is Wounded by the Strangeness', for his fellow Guantanamo prisoner - Salman al Khalifa. They were both separated by counterterrorism officers, and after a period of four months, Noaimi composed the poem to comfort and exalt his friend (Falkoff 61). He encourages his friend to remain patient and cheerful for his own good. He urges him to make sadness his captive by choosing happiness over it. He is highly philosophical in his description of sadness as an emotional response to pains, misery and repressive conditions. He explains the logic of his advice epigrammatically:

Hide the sadness of your heart as in a valley.

Make it your captive; if released, it will make you suffer (Falkoff 62).

The poet uses the captive situation to explain the psychological management of depressive conditions. To be free from sadness, one has to make sadness one's captive. Suffering is the repercussion for releasing sadness from captivity. What the poet suggests is not self-delusion or denial of reality, but rather the deliberate act of using aesthetics to diminish sadness or depression like a valley, and this allows the individual to rise above depression or misery. Noaimi makes this apparent:

My heart was wounded by the strangeness.

Now poetry has rolled up his sleeves, showing a long arm. (Falkoff 61).

The therapeutic power of poetry as a kind of psychological antidepressant is highlighted here. It frees the heart from sorrow. The poet makes this very clear as he addresses his friend; he affirms the potency of his poem:

Oh brother, who need not be named, I send you

My gift of greetings. I send heavily falling rains

To quench your thirst and show my gratitude.

My poem will comfort you and ease your burdens (Falkoff 62).

Poetry is metaphorically described here as 'heavily falling rains', capable of quenching the taste of the oppressed and distressed. The idea of poetry being born of suffering or being used as a moral compass is echoed in these lines. More importantly, the propensity of poetry to comfort those in distress is also well underscored.

Poetry means a lot to Guantanamo detainees. Subjected to the most appalling state of exception characterised with the absence of legal justice, poetry becomes the only veritable tool for self-preservation. In addition to this, it also affords the detainees the opportunity to interrogate and expose the forces of oppression, repression, and inhumane subjugation. Guantanamo poetry thus becomes a poetry of protest and indictment, articulating literary justice - albeit, "through the translation of "linguists" with secret-level se- curity clearances.' (Weber 426). Guantanamo poets use their poems to interrogate American democracy, and expose the hypocrisy of the so-called free world. Sami Al Haj's poem, "Humiliated in the Shackle", is perhaps the best example of such poems. Here, the poet laments the unfair treatment he has suffered in the hands of the Americans. He sees his incarceration as unjust - as an outrageous violation of his fundamental rights. The poet employs apostrophe which gives the poem it subtle, insightful, and satirical tone. This heightens the emotional quality of the indictment. The poet addresses his son, Mohammed, and George Bush as if they were physically present. Through his direct address to his son, he expresses feelings of nostalgia as he laments over his incarceration. He describes American democracy as appallingly hypocritical. He satirizes the so-called freedom, characteristic of American democracy as represented by the statue of liberty in New York, as mere architectural work:

They have monuments of liberty

And freedom of opinion, which is well and good

But I explained to them that

Architecture is not justice

America, you ride on the back of orphans,

And terrorize them daily (Falkoff 42-43).

The poet interrogates American democracy, and exposes the hidden injustice of the judicial system in relation to the war on terror. The statue of liberty which stands for freedom and justice has become a mere architectural work as it no longer represents what America does. The nation has become brutal, unlawful, and inclined to monstrous cruelty. This poem explains clearly what the $9 / 11$ attacks and the menace of post-9/11 Islamist terrorism have turned America into - an oppressive and cruel nation that now rides 'on the back of orphans'. Imagery of cruelty, oppression, and cowardly victimisation is very aptly associated in this poem with American foreign policies and imperialist activities. To 'ride on the back of orphans' implies oppressing the weak and helpless - bullying, intimidation and exploitation of less developed, less privileged nations or weaker nations. The situation is ironic; the irony, interwoven with the imagery of cruelty ascribed to America in the poem, is indeed reminiscent of Fredrick Nietzsche's popular philosophical truism:

Whoever fights monsters

should see to it that in the process

he does not become a monster.

And when you look long into the abyss,

the abyss also looks into you. (Nietzsche 89)

American responses to the $9 / 11$ attacks is clearly imaged in Nietzsche's truism. The treatment, humiliation and torture suffered by Guantanamo detainees clearly indicates that the war has made a monster of America. This is arguably what Jean Baudrillard means when he states that terrorism seeks to 'defy the system with a gift to which it cannot respond except by its own death and its own collapse' (Baudrillard 13-14). The American response to the $9 / 11$ attacks was not only robust, it amounted to a violation of its own laws, values, and principles. It is equally a violation of the Geneva Convention as evident in the indefinite detention and torture of Guantanamo detainees.

The experiences of Guantanamo detainees, as depicted in their poems, are not just appalling and inhumane; they 
also constitute a clear violation of the principles and values that underpin modern democracies. More to the point, the action of the United States and its agents as evident in the inhumane treatment of the detainees also violates not just the laws of the United States, but all international laws and the Geneva Convention to which the United States is equally a signatory. It may be argued that the torture and 'indefinite' detention of the detainees took place outside the legal jurisdiction of the United States - that is, on foreign soil to which the laws of the United States are not applicable. The question is this. Was Guantanamo military base truly a 'legal equivalent of outer space' as conceived by some of George W. Bush's government officers?' (Packard). While it may not be necessary to examine the intricacy and practical details of relevant international laws, this question will probably help determine whether Guantanamo was in practical terms an outer space, legally or juridically speaking. If some terrorist group or foreign power had attacked Guantanamo Bay military base, would it had been considered as an attack on an outer space or as an attack against the United States? Of course, such attack would have had the same effect as the attack on the United States Embassy in Benghazi and Nairobi. The argument that Guantanamo was an outer space to which no law applies is heavily flawed.

Moreover, the United States is a signatory to the Geneva Convention. This implies that the United States has agreed to comply with the Geneva Convention in all its actions and activities, home or abroad. If the action of the United States or its agents - home or abroad - contravene the Geneva Convention, it would amount to the United States acting in breach of its solemn international obligations. The Geneva Convention prohibits torture and detention without trial, which were the very actions of the United States agents at Guantanamo Bay Prison Camp (Zeyas 20-21).

The issues highlighted and argued above bring to the fore the contiguity between a state of exception and sovereignty. For one thing, the institutionalisation of Guantanamo Bay Prison Camp best exemplifies a state of exception as a legal situation (Agamben, "State of Exception" 12). As highlighted earlier, the state of exception is a legal theory proposed by Carl Schmitt (a German jurist and political theorist) and further developed by Giorgio Agamben (an Italian philosopher). It is difficult to give a precise definition of the state of exception (Agamben, "State of Exception" 2). I have previously proposed tentatively that the state of exception is similar to a state of emergency, except that it is based on the sovereign's power of the state to transcend the rule of law in the interest of the public. To discuss the contiguity between state of exception and sovereignty, it is important to start with Carl Schmitt, who first proposed the state of exception as a legal theory. According to Carl Schmitt, a sovereign solely determines a state of exception; all laws are situational. It is the sovereign that 'produces and guarantees the situation in totality' (Schmitt 13). As a sole determinant of the situation, the monopoly of the sovereign requires a precise juridical/legal definition. Schmitt posits that the 'monopoly to coerce or to rule' differs from the 'monopoly to decide', and that the sovereign has the 'monopoly to decide' and not the 'monopoly to coerce or to rule' (Schmitt 13).
What then is the exception? Schmitt theorises that the exception is clearly indicative of the essence of the authority of the state. Understandably, the exception is paradoxical as it amounts to producing laws, which 'need not be based on the law' (Schmitt 13).

The paradox highlighted above informs Agamben's affirmation that the state of exception is difficult to define precisely because of its proximity to other situations like civil war, insurrection, and resistance, or with conditions that contrast the normal. It thus remains in the region of undecidability, and as Agamben puts it, it translates as 'state power's immediate response to the most extreme internal conflicts' ("State of Exception" 2). It is quite tempting to associate the theorisation of the state of exception to the Nazi state. Schmitt, as a Nazi ideologue, was an incisive critic of Weimar liberalism, which he construed as 'Jewish'. He theorized sovereignty at the time of German transition from Weimar to the Nazi Reich. Agamben, in an attempt to explain the paradoxical situation which has been categorically described as 'legal civil war' or 'global civil war', recalls that soon after Hitler took power, he proclaimed the decree of the Protection of the People and the State, which effectively suspended the article of the Weimar Constitution about personal liberties. The decree was however never repealed, and consequently, the Third Reich became a state of exception that lasted for twelve years (Agamben, "State of Exception" 2). In this regard, modern totalitarianism is established by means of a state of exception - a kind of 'legal civil war' - which permits the physical expunging of 'political adversaries', and sometimes, an entire group of citizens who are not assimilated into the political system (Agamben, "State of Exception" 2). Agamben also maintains that the intentional creation of a permanent state of emergency is not only descriptive of the Nazi Reich, but 'has become one of the essential practices of contemporary states, including so-called democratic ones' ("Sate of Exception" 2).

Significantly, in an effort to explain the biopolitical significance of the state of exception, Agamben gives several examples, but most strikingly, the 'military order' issued by the United States' president, George W. Bush, on the $13^{\text {th }}$ of November 2001. The military order categorically approves the indefinite detention and trial by 'military commission' of non-citizens, who are suspected of terrorist activities (Agamben 2; Weber 425). Meanwhile, the United States Patriot Act, which was enacted on the $26^{\text {th }}$ of October 2001 , already made similar, but less draconian provision. The said act authorises the Attorney General to apprehend and detain aliens who are suspected of activities that can jeopardise the national security, but the alien should either be charged or released within seven days (Agamben "State of Exception" 2; Ball 7). There was something new in the order Bush issued, which was totalitarian or anti-democratic; it completely effaced any legal status of the alien-individual. In other words, the detainees do not have the status of the prisoners of war or the status of persons charged with crime according to American laws. In fact - as Giorgio Agamben affirms - Guantanamo detainees, more like the inmates of Nazi concentration camps, have no legal identity at all (Agamben, "State of Exception" 2-3).

Guantanamo detainees in their poems lament not only about the physical torture to which they were persistently 
subjected, but the psychological torture resulting from the complete absence of the hope, which is guaranteed legally or juristically in normal situation. Being living beings with no legal status whatsoever amounts to a state of non-existence. The detainees thus become the 'homo sacer' or the 'bare life' as Agamben puts it (Agamben, "Homo Sacer" 8; Agamben, "State of Exception" 2-3). This concept will be discussed in detail later in relation to the biopolitics of exclusion integral in the state of exception. At this point, it is important to stress that the military order issue by Bush was not just dehumanising, it denies Guantanamo detainees the right of existence, and that was a traumatic experience that arguably goes beyond terror. The state of non-existence, or of gradual psychological suffocation, culminating in physical death resulted in the desperate use of poetry (by Guantanamo detainees) not only as a means of resuscitation, of 'breathing in and breathing out', but also as a way of sharing life with others. Chilean-American novelist, playwright, essayist, academic, and human rights activist, Ariel Dorfman, attests to this:

What I sense is that the ultimate source of these poems from Guantanamo is the simple, almost primeval, arithmetic of breathing in and breathing out... And the written word is nothing more than the attempt to make that breath permanent and secure, carve it into rock or mark it on paper or sign it on a screen, so that its cadence will endure beyond us, outlast our breath, break the shackles of solitude, transcend our transitory body and touch someone with its waters. Breathing in and breathing out. What these prisoners shared with their jailers... with men who incarcerated them and feared them and saw them only as the enemy. Poetry as a call to those who breathe the same air to also breathe the same verse, to bridge the gap between bodies and between cultures and warring parties. And that is the deeper, and perhaps more paradoxical significance of the appearance of these poems in the United States, rescued by American lawyers, printed by an American Press, copyedited by American eyes, published in the very heartland, the very centre, of the nation that has so maltreated these men. (Dorfman 71).

In addition to the 'arithmetic of breathing in and breathing out', resuscitation, sharing, and bridging the gap between bodies, cultures, and 'warring parties', Dorfman points out here a striking irony about Guantanamo poetry. While America as a nation is responsible for the maltreatment of the detainees, it is ironic that an American press is responsible for the publication of these poems; moreover, US lawyers also collected the document.

The situational irony highlighted above stresses the complexity of the situation (and of America as a society). The situation is undoubtedly evocative of William Blake's philosophical claim that contraries are essential elements of progression. Blake - in his book, The Marriage of Heaven and Earth (1975) - states:

Without Contraries is no progression. Attraction and Repulsion, Reason and Energy, Love and Hate are Necessary to Human existence.

From these contraries spring what the religious call Good and Evil. Good is the passive that obeys Reason.
Evil is the active springing from Energy (Blake xvi).

The idea here is that there is no linear society. In any society (including the United States), two opposing forces are constantly at work. More importantly, these forces tend to be present in every individual. German playwright and statesman, Johann Wolfgang von Goethe, in his play, Faust, dramatizes the duality of man's true nature through the character of the protagonist. Goethe's protagonist, Faust, states:

Alas, I house two souls in me

And each from each wants separation.

With love, with rough delight, keenly the one

Holds to the earth, with battering organs, fast

The other by main force lifts from the dust

Into the realms of the high ancestry (Goethe 39)

The duality of man's nature or the duality of the human society, described as contraries by William Blake, is reflective of Apollonian and Dionysian forces as the two opposing forces in human nature. In Greek mythology and tradition, Dionysus and Apollo are both sons of Zeus and notable gods of the creative arts. Dionysus is believed to be the sensual god, the god of wine, music and ecstasy. Apollo, on the other hand, is associated with light, eloquence, justice, morality, purity, elevated thought, restraint and order. Briefly put, while Dionysus represents the 'irrational', Apollo is a symbol of 'rational thought' (Calarco 8; Hammer 71).

The war on terror (driven by much energy, irrational hate, revenge, and to be argued below, by Orientalism and biopolitics) is Dionysian in nature with its ecstasy of rage as exemplified in the indefinite detention, torture, and repression of Guantanamo detainees. The Apollonian light, eloquence, justice, morality, elevated thoughts, restraint, and order are not only manifested in the compassionate and just action of the US lawyers and activists who fight for the right of the detainees, but also in Guantanamo poetry itself. For one thing, the detainees use poetry not only to resuscitate their lives (which were exterminated by the effacement of their legal status or by means the state of exception) but also, to question the morality of their oppressors, demand justice, express rational and elevated thoughts, and, as in the process of breathing in and out, share their lives with others who breathe the same air. In the process, they immortalise their existence through poetry. Ibrahim al Rubaish's poem, "Ode to the Sea", exemplifies this. It is a beautifully written poem in which the poet addresses the sea as if it has human qualities. The sea becomes a metaphor of the world. The poet is not angry with the capturer or the oppressor of the detainees, but with the world that watches the brutality, torture, and humiliation of the detainees with indifference. The poet complains bitterly of the injustice he and other detainees have suffered in the hands of the Americans. He directed his anger to the sea for being indifferent, complacent, cruel, and for being a collaborator:

Your stillness will kill the captain if it persists,

And the navigator will drown in your wave.

Gentle, deaf, mute, ignoring, angrily storming,

You carry graves. (Falkoff 65)

The stillness of the sea symbolises the way the nations of the world have abandoned them helplessly in the cruel and tormenting hands of the American government. The sea is 
not only deaf to their cries and anguish; it has also refused to let them know the crime they have committed:

Do you know our sins?

Do you understand we were cast into this gloom?

O sea, you taunt us in our captivity.

You have colluded with our enemies and you cruelly guard us (Falkoff 65)

These detainees have not had their day in the court; they have not been charged with any offence, yet they suffer brutality, physical and psychological torture, and indefinite detention. The sea separates the poet from America for the three years of his incarceration at Guantanamo:

You have been beside us for three years, what have you gained?

Boats of poetry on the sea; buried flame in burning heart The poet's words are the font of our power;

His verse is the salve for our pained hearts (Falkoff 66)

The function of aesthetic (and more specifically, poetry), as the very giver of life and as the force of immortalisation of beings and their experiences, is imaged in the above lines. The words - that is, the verses, which they attempt to share with America and the rest of the world - is metaphorically compared to boats on the sea. As the boats stay afloat, they will continue to live, although they have no legal identity. Poetry has given them the identity which the state of exception has effaced. These boats will convey their message to different lands; the boats will also outlive their creators. The poet avers: 'the poet's words are the font of our power' (Falkoff 66). In this line, the poet affirms the power of aesthetics which can render ineffectual the brutality of the state of exception.

Ustard Badruzzam Badr's poem, 'Lions in the Cage', also buttresses the power of aesthetic. The poem underscores the idea that aesthetics can give identity to, and of course, immortalise those effaced by state of exception. Poetry helps to give identity, recognition and immortalisation to the detainees who were denied legal status or identity by the $13^{\text {th }}$ November 2001 'military order' of George W. Bush. As the poet laments over the incarceration of the prisoners, he affirms their heroism, lion-like bravery and immortality through the power of aesthetics:

We are the heroes of the time.

We are in the proud youth.

We are the hairy lions.

We live in the stories now.

We live in the epics.

We live in the public's heart (Falkoff 28).

Though the detainees have no legal identity, they will continue to live forever in 'stories' or 'epics' and in 'the public's heart' by means of aesthetic immortality (Falkoff 28).

The poet combines lamentation and fortitude; he eulogises the courage of the prisoners, comparing it to a mountain. The mountainous courage of the prisoners ironically threatens their corrupt oppressor who has become restive in the 'White Palace'. Using a subtle combination of metaphor and metonymy, he describes George W. Bush as the "Pharaoh of our time" and as "the chief of the White Palace" (Falkoff 28). In Badr's poem, poetry is closely associated with tears, pains, and suffering. The prisoners have no weapons but their tears in the cage, hyperbolically described as a whirlpool, soon form a flood - strong enough to make George W. Bush restless as it moves rapidly towards Washington. What the poet attempts to image here may be best described as 'literary justice', which vindicates the innocent as it exposes the injustice and cruelty of the oppressor. There is some degree of timelessness, or immortality in literary justice, unlike legal justice. This is probably what contributes to the restlessness of 'the chief of the White Palace' (also described in the poem as 'The Pharaoh of our time') (Falkoff 28). Through poetic immortality, the 'Chief of the White Palace' (that is, President Bush) will be remembered forever for his cruelty. Guantanamo Prison Camp will also remain a case study for the illegality of the state of exception. The poet's affirmation in relation to the power of the flood is thus a metaphorical description of the power of literary justice: 'No one can endure the power of this flood' (Falkoff 28).

Moreover, the metonymic substitution of 'chief' for 'president' and 'White Palace' for 'White House' in the poem is satiric and sarcastic. It equates American democracy (and perhaps, Western democracies in general) with the totalitarianism and dictatorship characteristic of monarchical governments

The ironic hypocrisy of modern democracies, as evident in the institutionalisation of a permanent state of exception, is also clearly mirrored in the experiences of another Guantanamo detainee, Mohammed El-Gharani. Gharani, a fourteen-year-old boy, is a Chadian national brought up in Saudi Arabia. He went to Pakistan with the sole aim of studying English and Information Technology, but he was arrested and tortured by the Pakistani police and later transferred to the custody of the United States (Falkoff 37). In Gharani's biography note, the editor of Poems from Guantanamo: The Detainees Speak reports:

They hanged him by his wrists - nearly naked, his feet barely touching the floor - and beat him if he moved. When told he would be transferred to U. S. custody, Gharani was overjoyed, thinking that his torture would end. Under the U. S. custody in Kandahar, Afghanistan, however, he was also stripped and beaten. In January 2002, he became one of the first 'enemy combatants' transferred to Guantanamo Bay... (Falkoff 37).

The ironic experience of Gharani is poetically chronicled in his poem, "First Poem of my Life". The poem mirrors the physical and psychological torture he suffers in the hands of Pakistani and American security agents. Hypocrisy, betrayal, and injustice constitute the central idea that runs through the poem. The poem begins on this note:

Move it cautiously in the land of those who speak no Arabic,

Even if they give you oaths bound by oaths.

Their aim is to worship petty cash.

And for it they break all vows.

I came to their land to pursue an education,

And saw such malice among them

They surrounded the mosque, weapons drawn,

As if they were in a field of war (Falkoff 38).

While the poet finds the greed and corruption of the $\mathrm{Pa}-$ kistani security appalling, he finds the injustice, torture, and 
humiliation he suffers at the hands of the American security officers astonishing. He concludes that this is not a war against terrorism but a war against Islam and justice.

Furthermore, what makes the 'war' unjust is not only the dehumanisation of innocent detainees, but the hypocrisy of the state, which is inherent in the state of exception. Agamben's reading of Schmitt's state of exception theory does not only highlight the monopolistic power of the sovereign, who alone determines or declares a state of emergency, while it stays outside the law, but also the conception that it is the nation that needs to be protected from its others (Agamben, "State of Exception" 1-3). This notion is questioned in the poems of Guantanamo detainees. These poets demonstrate their helplessness, fragility, and feebleness in the hands of the United States. While the Bush administration describes them as 'extremely dangerous' people, Guantanamo detainees - in their poems - portrays the United States as a powerful, cruel, and corrupt nation. The detainees, as evident in their poems, are at the mercy of the United States agents. Though Guantanamo poets employ poetry to express their defiance, beneath the words of defiance are deep lamentation, melancholy, apprehension, uncertainty, and nostalgia. This is well exemplified in Shaik Abduraheem Muslim Dost's "Two Fragments". As the title suggest, the poet's feelings or thoughts are fragmented, and this informs the structure of the poem. Structurally, the poem consists of two parts - Fragment One and Fragment Two, each comprising three stanzas of equal lines. In the first fragment, the mood is that of melancholy. The poet is nostalgic as he celebrates his Eid (Muslim festival) alone in the cage, and eats his bread in tears:

Eid has come, but my father has not.

$\mathrm{He}$ is not come from Cuba.

I am eating the bread of Eid with my tears.

I have nothing.

Why am I deprived of the love of my father?

Why am I so oppressed? (Falkoff 36).

The poet laments here over his incarceration, which denies him of the love, companionship, and care of his father. $\mathrm{He}$ is apparently weak and helpless. He needs to be protected from the extra-legal legality of the state.

In the second part of the poem (Fragment Two), the poet, in a manner characteristic of the poetry of Guantanamo detainees, uses his poem as a psychological shield against depression by expressing defiance. He rises above the melancholy expressed in Fragment One, and blossoms in hope. $\mathrm{He}$ is philosophical as he attempts to explicate the idea of freedom and slavery. The poetic construction of freedom is predicated on the freedom of thought, and thus diminishes the psychological impact of his physical incarceration:

Those who have no courage or honour considered themselves free,

But they are slaves.

I am flying on the wings of thought,

And so, even in this cage, I know a greater freedom (Falkoff 36).

To the poet, freedom does not consist in the freedom of movement, but in the capacity to think freely and hold views, which may be unpopular with the state. Some forms of conformity, which militate against the freedom of thought, are not only dishonourable, they amount to slavery. The contrast between slavery and freedom as depicted in the poem is paradoxical. This paradox gives the poem its aesthetic excellence, and at the same time, enables the poet to rise above the pervading melancholic atmosphere in Fragment One.

Putting Guantanamo into perspective, one cannot help asking these questions repeatedly: "Was the state of exception as it applies to Guantanamo detainees (and perhaps, the war on terror in totality) really necessary? What magnitude of threat could these detainees constitute to a powerful nation like the United States? Would it not have been possible to mitigate the threat if it so exists under the rule of law? One idea resonates well with Guantanamo poetry - that is, the poems tend to constantly draw our attention to the ways in which Bush administration's post-9/11 state of exception promoted American imperialism whereby the so-called enemy combatants are considered not as prisoners of war or criminals, but as both colonial subject and object. In line with this assertion, Stephen Morton argues that the discourse of contemporary postcolonial terrorism is quite often used to justify 'the expansion of US and British military power in the twenty-first century' (Morton 36). Morton maintains that the war in Afghanistan, the British and American military occupation of Iraq and support of Israel's occupation of West Bank are all part of this expansion, and thus described the contemporary postcolonial terrorist as 'an effect of colonial discourse that is presented as a cause'(Morton 36). This explains why Guantanamo detainees were treated not just as colonial subjects, but equally as mere objects of the United State imperialism - dissidents or scapegoats needed to demonstrate the power of the colonial authority over its subjects. This assertion resonates with Foucault's discussions in Discipline and Punish: The Birth of the Prison (1977). He argues that punishment does not serve a reformative function, but helps to establish the power of the authority of the state (or the king). Foucault maintains that while the eighteenth century witnessed calls for the reform of punishment, the reformers - who were actually motivated by the need to make the operation of power more efficient - had no concern for the welfare of the prisoners ("Discipline and Punish" 15).

Arguably, Guantanamo detainees write their poems not just in 'captivity' as in the case of prisoners of war, but as colonial subject and object. Osama Abu Kabir acknowledges this in his poem, 'Is it true?' - a poem of sorrow, in which the poet pleads his innocence and intensely expresses nostalgic feelings. He appeals passionately to the conscience of the imperial power that puts him and other Guantanamo detainees in the prison cage:

But do you hear me, oh judge, do you hear me at all?

We are innocent, here, we've committed no crime.

Set me free, set us free, if anywhere still

Justice and compassion remain in this world!" (Falkoff 50)

It is not the captivity of the detainees that makes them the object of American imperialism. Their incarceration if enforced under the rule of law would have made them subjects of the state. As subjects of the United State imperialism, they are under the authority of the United States - the same au- 
thority that took them into custody and denied them of the protection of the Geneva Convention. Moreover, what makes them mere colonial objects is their 'innocence' - the fact that they have been chosen or randomly selected to demonstrate the authority of colonial power over its subjects. One may argue that the claim relative to the innocence of Guantanamo detainees is problematic, but there are legal grounds for this assertion. First, suspects of any crime under the law are presumed innocent until they are proven guilty (Elsea and Fisher 14). Secondly, these detainees cannot be considered as terrorism suspects since charges were not brought against them. This is precisely the case presented in this poem: "We are innocent, here, we've committed no crime/Set me free, set us free..." (Falkoff 50). Through the subtle appeal of the poet, the Bush administration is revealed as colonial and totalitarian. The poet has no other authority to appeal to, except the United States because he has been made a subject, and at the same time, an object of the United States imperialism. To further illuminate the concept of colonial subject and object, it may be expedient to revert to Giorgio Agamben.

\section{THE BARE LIFE AS A POLITICAL SUBJECT AND OBJECT}

A constant state of exception, as agued by Agamben in Homo Sacer: Sovereign Power and Bare Life (1998), gives the state the power to turn the lives of those who are under its rule into homo sacer or 'bare life'. Homo sacer (meaning, 'sacred man') is a Roman concept used to imply or describe he who 'may be killed and yet not sacrificed' (Agamben, "Homo Sacer" 8) Agamben does not only employ the concept of homo sacer to theorise the 'bare life' of Nazi concentration camps, he equally extends it to Guantanamo detainees to whom the Geneva Convention and United States laws do not apply (Agamben 8; Agamben 2-3). Agamben explains the application of the state of exception in the entire political system:

At once excluding bare life from and capturing it within the political order, the state of exception actually constituted, in its very separateness, the hidden foundation on which the entire political system rested. When its borders begin to be blurred, the bare life that dwelt there frees itself in the city and becomes both subject and object of the conflicts of the political order, the one place for both the organisation of state power and emancipation from it (Agamben, "Homo Sacer" 9).

The blurring of the line in relation to the state of exception as theorised by Agamben is evident in Abdullah Anazi's poem - "To my Father". The poem clearly points at the way the exclusion and capturing of 'bare life' occurs within the state of exception. It is a highly nostalgic poem, in which the poet laments over his two years of imprisonment at Guantanamo Prison Camp. The poem is intended as a message to the poet's father, whom he misses so dearly. Addressing his father as though he is physically present, he complains about the injustice represented by his incarceration. He pleads his innocence, while urging his father to give his greetings to all his relatives, neighbours, and friends. He laments over the betrayal he suffers from those, who despite his inno- cence, sold him to the Americans. He dwells on the theme of betrayal as he portrays himself as a homo sacer or form of 'bare life' whose freedom or captivity depends on the political caprices of the state. The poet does not only plead his innocence, he equally reveals how he has been tempted by American terrorism officer to work for them in an exchange for his freedom and a pleasant life:

They tempted me to turn away from the lofty summit of integrity

To exchange this cage for a pleasant life.

By God, if they were to bind my body in chains,

If all Arabs were to sell their faith, I would not sell mine (Falkoff 25).

The poet is resolutely determined not to betray his faith and principles, and therefore, refuses to kowtow to the intrigue of the political order. However, the intrigue of the political power as symbolised in the temptation (or the conditioner offer of freedom to the poet) may be seen as the blurring of the line in relation to the state of exception. This, according to Agamben, produces 'citizens' who are both subject and object of the political order; When the borders of the political system 'begin to be blurred, the bare life that dwelt there frees itself', and in the process, 'becomes both subject and object of the conflicts of the political order' (Agamben, "Homo Sacer" 9).

The representation of the state of exception in Guantanamo poetry shows that the state of exception is arguably the 'weapon' of the powerful against the weak - the weapon of a powerful state against a category of its subject or homo sacer ('bare life'), who are by means of this weapon reduced to mere objects of the state. The fact that the state has to stay outside the law to produce this weapon casts aspersion on the necessity of states of exception. Perhaps more importantly, it may as well lead us to the conclusion that the state of exception is not just a 'legal civil war' or 'global civil war' as Agamben puts it ("State of Exception” 2), but a calculated attempt to legalise lawlessness. It is a calculated attempt to create a space for the unfair treatment of a category of citizens whom the state has decided to exclude from the protection of the law. Arguably, the 'state of exception' - in contrast to Agamben's claim - cannot be truly considered as law; it is in practical terms a suspension of the law, or simply put, it is a situation in which an exception is made regarding the applicability of the law to a category of people in an effort to create a legal limbo for the 'enforcement' or perpetration of lawlessness. The rationalisation of lawlessness because of presumed existence of the state of necessity, which apparently has no juridical form, is what I describe in this article as extra-legal legality - an oxymoronic expression which constructs Bush administration's post-9/11 state of exception as an undemocratic legal limbo.

Agamben's affirmation that the state of exception is the 'hidden foundation on which the entire political system rested' ("State of Exception" 9) may be overreaching. I will submit that a state of exception is underpinned by the logic of exclusion (and not inclusion). A situation of exception cannot reasonably constitute the very foundation of the normal or be presumed more important than the normal as Schmitt argued. Though the exception may appear as a 'critique' of 
the normal as it points at the very limit of the law and prioritises the lawless over the lawful, this limitation is self-imposed. It is a situation whereby the sovereign decides on a territory which exists outside the rule of law because of the existence of a presumed state of necessity. Agamben equally casts aspersion on the legitimacy or correctness of the state of necessity as theorised by Schmitt (12-13). For instance, was Hitler's decree of the Protection of the People and the State a product of the state of necessity at the time? Or, was the $13^{\text {th }}$ November 2001 military order of Bush administration, which approves the indefinite detention and trial by 'military commission' of non-citizens suspected of terrorist activities, really necessary? It is tempting to answer these questions in the negative, considering the non-existence of a substantial threat to the security of the states in question.

The blurring of the line as theorised by Agamben, in my opinion, is the integration of the indigenous other ('bare life') into the political order. The state of exception exists for the 'other' only when the sovereign decides on their exclusion. Both Schmitt and Agamben are unanimous about the power of the sovereign to decide. If this is true, the state of exception as a situation of exception, subject to the sole discretionary decision of the sovereign, cannot constitute a hidden principle or foundation of the normal or the rule of law. To say that state of exception is the 'hidden foundation on which the entire political system rested' may amount to theorising for the legalisation of lawlessness through 'subtle' indulgence in false binaries. The state of lawlessness is the absence of the rule of law as evident in the exclusion of a category of people from the protection of the law. The excluded is therefore not assimilated into the political order.

In line with Agamben's position, the state of exception is one of the results of the biopolitics of modern democracies such as the Israeli state of exception in the West Bank and Gaza Strip, the state of exception characteristic of Nazi Germany and the United States post-9/11 state of exception. Nevertheless, since both biopolitics and state of exception negate the principles and values of modern democracies, it may not make much sense to argue that the state of exception is the 'hidden foundation on which the entire political system rested' as posited by Agamben ("Homo Sacer" 9). This brings to the fore the discourse of otherness, which is arguably integral to biopolitics, and at the same time, makes the state of exception important in the war on terror.

Detention without trial and the deployment of airstrikes in civilian neighbourhoods are not only unlawful acts or war crimes under the terms of international law; they are also reflective of a post-9/11 state of exception. As argued earlier, these unlawful acts, on the part of the state, are informed by biopolitics and not by the 'state of necessity'. Michel Foucault argues that politics turns into biopolitics when life becomes included in the mechanism of the state power. He describes this phenomenon as 'biopower'. Biopower, according to Foucault, creates 'docile bodies' through a series of governmental technologies. This eventually makes the population (its life, longevity, health, and welfare) the object of the government (Foucault "The History of Sexuality" 138-139). At the Collège de France, Foucault dedicated a series of lectures he delivered in the 1970s to the birth of racism; in these lectures, he traces the progression from the power of the sovereign to kill people presumed unwanted to the biopower of the modern states which is directed at their living beings or population (Morton and Bygrave 8 ). To Foucault, racism is an ongoing social war, which is fostered by the biopolitical technologies of purification ("Society Must be Defended" 133, 316-318).

The discourse of otherness is implicit in Foucault's description of biopolitics and biopower because they both produce racial states. David Theo Goldberg equally buttresses this position or notion. Goldberg theorises modern nation-states as racial states. State power, according to Goldberg, excludes so as to construct homogeneity. He describes governmental technologies used to achieve exclusion of the racialized other, and these include constitutions, the law, border control, population census, policy making, invented histories and traditions, ceremonies and cultural imaging, and so on (Goldberg 195). While the state of exception may be the result of biopolitics, it is rationalised by what Schmitt describes as a 'state of necessity' - the need for the state to defend itself against its indigenous minorities or migrant 'other' (13). As argued earlier, such need has no apparent historical existence, and definitely not in the case of Guantanamo detainees. I will posit that the 'Other' is bio-socially (that is, racially, socially and culturally) determined. Biopolitics is thus closely linked to the politics of race, and therefore inherently interlaced with the discourse of otherness. The discourse of otherness inherent in biopolitics is also suggestive of the link between post-9/11 state of exception and Orientalism. This link may be described as the biopolitics of Orientalism, which is synonymous with the biopolitics of the state of exception. This is arguably what makes post-9/11 extra-legal legality or the post-9/11 wars in general the case of orientalism in a state of exception.

In Said's Orientalism (1978), he describes Orientalism as 'a political vision of reality whose structure promoted the differences between the familiar (Europe, the West, "us") and the strange (the Orient, the East, "them")' (43). Said argues that the vision of the Orient has become an engrained structure of thought in that it is a 'distribution of geographical awareness into aesthetic, scholarly, economic, sociological, historical, and philosophical texts' (12). Orientalism does not only involve considering Arab culture as exotic, uncivilized, barbaric, and sometimes, dangerous, it promoted differences. The biopolitics of these differences places less value on the lives of the 'oriental other'. To revert to Agamben, the 'oriental other' becomes the homo sacer ('bare life'). Thus, the discourses of 'otherness' engrained in Orientalism somehow 'justify' post-9/11 state of exception as evident in the use of colossal war weaponry in civilian neighborhoods (in Iraq, Afghanistan, Yemen, Pakistan, and so on) and in the indefinite detention and torture of Islamist terrorism suspects, who, arguably, do not constitute substantial risk to the United States. Orientalism contributes to post-9/11 state of exception in the same way many scholars (including Edward Said) believe it 'contributed to the formulation of colonial law and the justification of its suspension during conditions of emergency, or a threat to the sovereign of the colonial state' (Morton 36). 
When we consider Guantanamo poetry as poems of lamentation and protest, we can easily figure out the object of their lamentation and protest - that is, the biopolitics of orientalism, which provide the illicit 'justification' for the inhumane treatment they suffer in the hands of the Americans. These poets use aesthetics not only as a shield against depression characteristic of their incarceration, but to lament over their unfair treatment while protesting the biopolitics of orientalism, which exclude them from the protection of the law. For instance, Rubaish in his poem, 'Ode to the Sea', directs his anger at the sea. The sea is not only personified through the combinations of images, it emerges as the world itself - a racialized world of injustice characterized by the biopolitics of exclusion. The sea itself metaphorically represents this exclusion: 'Your beaches are sadness, captivity, pain, and injustice' (Falkoff 2007, p. 65). The sea is presented also as a guard, and like the US soldiers, it ensures that they cannot escape: "You have colluded with our enemies and you cruelly guard us'. The biopolitics of this captivity and exclusion is what the 14-year old poet-combatant, Mohammed El Gharani, reveals in the last two lines of his poem - "First Poem of my Life":

Out of spite, they showed such impudence.

Their war is against Islam and justice (Falkoff 39)

Unlike other Guantanamo poets (who are unsure of the sin they have committed against America to deserve their incarceration), Gharani is certain: the war is not against terrorism or terrorists. It is simply against Muslims, who are the object of the biopolitics of exclusion. This assertion resonates with Stephen Morton, who observes that 'the war on terrorism has also been waged as a war against Muslims'(Morton 18). The war is not only against Islam and Muslims, but also against justice because the biopolitics of exclusion, which underpin the war on terror, is undemocratic, illicit, and morally indefensible.

\section{CONCLUSION}

Guantanamo poetry clearly belongs to the genre of post9/11 literature. It epitomizes the spirit of the post-9/11 era. For one thing, Guantanamo poems are not only reflective of the politics of fear and exclusion that typifies the post9/11 era; they also successfully transcend the barriers of cultural differences, mitigate against fear, ignorance, and hate through the concrete depiction of mutuality in the experience of suffering. These poems thus inadvertently invite us to embrace our common humanity with compassion. Notably, the aesthetics of the poems makes Guantanamo poetry of enormous significance. It portrays the detainees as political subjects and objects - as victims of extra-legal legality, of the post-9/11 state of exception driven by Orientalism and biopolitics.

\section{REFERENCES}

Agamben, Giorgo. Homo Sacer: Sovereign Power and Bare Life. Stanford: Standford University Press, 1998. Print.

---. State of Exception. Chicago: University of Chicago
Press, 2005. Print.

Ball, Howard. The USA Patriot Act of 2001: Balancing Civil Liberties and National Security. Santa Barbara, CA: ABC-CLIO, Inc., 2004. Print.

Baudrillard, Jean. The Sprit of Terrorism. London: Verso, 2012. Print.

Blake, William. The Marriage of Heaven and Hell. Oxford: Oxford University Press, 1975. Print.

Calarco, J. N. Tragic being: Apollo and Dionysus in Western Drama. Minneapolis: University of Minnesota Press, 1969. Print.

Dorfman, Ariel. "Where the Buried Flame Burns." Poems from Guantanamo: The Detainees Speak. Ed. Marc Falkoff. Iowa City: University of Iowa Press, 2007. 69-72. Print.

Elsea, Jennifer, and Louis Fisher. Suspected Terrorists and what to do with Them. New York: Novinka Books, 2006. Print.

Falkoff, Marc, ed. Poems from Guantanamo: The Detainees Speak. Iowa City, IA, USA: University of Iowa Press, 2007. Poems from Guantanamo: The Detainees Speak. Print.

Farrell, Michelle. The Prohibition of Torture in Exceptional Circumstances. Cambridge: Cambridge University Press, 2013. Cambridge Core. Web. 2017/11/12.

Felman, Shoshana. The Juridical Unconscious: Trials and Traumas in the Twentieth Century. Cambridge, MA: Harvard University Press, 2002. Print.

Foucault, Michel. Discipline and Punish: The Birth of the Prison. New York: Vintage Books, 1977. Print.

---. The History of Sexuality, Vol. 1: The Will to Knowledge. London: Penguin, 1990. Print.

---. Society must be Defended: Lectures at the College De France, 1975-76. London: Allen Lane, 2003. Print.

Goethe, Johann Wolfgang. Faust, Part 1. London: Penguin Books Ltd, 2005. Print.

Goldberg, D. T. The Radical State. Oxford: Blackwell, 2002. Print.

Greene, Roland, et al, ed. The Princeton Encyclopedia of Poetry and Poetics. $4^{\text {th }}$ ed. Princeton: Princeton University Press, 2012. Print.

Hammer, L. "Apollo and Dionysus." American Scholar 77.4 (2008): 64. Print.

Hoyles, John. The Edges of Augustanism: The Aesthetics of Spirituality in Thomas Ken, John Byron, and William Law. Berlin: Springer Science and Business Media, 2012. Print.

Liesen, Laurette T., and Mary Barbara Walsh. "The Competing Meaning of 'Biopolitics' in Political Science." Politics and Life Science 31.1-2 (2012): 2-15. Print.

Morton, Stephen. "Writing Muslims and the Global State of Exception." Culture, Diaspora, and Modernity in Muslim Writing. Eds. Rehana Ahmed, Peter Morey, and Amina Yaqin. New York: Routledge, 2012. 18-33. Print.

Morton, Stephen, and Stephen Bygrave. "Introduction." Foucault in an Age of Terror: Essays on Biopolitics and the Defence of Society. Eds. Stephen Morton and Stephen Bygrave. Basingstoke: Palgrave Macmillan, 2008. 1-13. Print.

Morton, Stephen. "Terrorism, Orientalism and Imperialism." Wasafiri: The Transnational Journal of International Writing 22.2 (2007): 36-42. Print.

Mullins, Greg A. “Atrocity, Literature, Criticism.” Amer- 
ican Literary History 23.1 (2011): 217-27. Print.

Nietzsche, Friedrich. Beyond Good and Evil. Trans. Walter Kaufmann. New York: Vintage Books, 1966. Print.

Packard, Scott. "How Guantanamo Bay Became the Place the U. S. Keeps Detainees: A Former Marine Looks Back on His Tenure Commanding the Now-Infamous U. S. Naval Base." The Atlantic, 2013, Print.

Panush, R. S., et al. "Retraction of the Suggestion to use the Term "Reiter's Syndrome" Sixty-Five Years Later: The Legacy of Reiter, a War Criminal, should Not be Eponymic Honour but rather Condemnation." Arthritis Rheum 56.2 (2007): 693-4. Print.

Ramraj, Victor V. "No Doctrine More Pernicious? Emergencies and the Limits of Legality." Emergencies and the Limits of Legality. Ed. Victor V. Ramraj. Cambridge: Cambridge University Press, 2008. 3-30. Web.

Reid, David. The Metaphysical Poets. London: Routledge, 2013. Print.

Said, Edward W. Orientalism. London: Routledge and Kegan Paul, 1978. Print.
Schmitt, Carl. Political Theology: Four Chapters on the Concept of Sovereignty. Chicago: The University of Chicago Press, 1985. Print.

Stella, Francesca, and Nadya Nartova. "Sexual, Citizenship, Nationalism, and Biopolitics in Putin's Russia." Sexuality, Citizenship, and Belonging: Trans-National and Intersectional Perspectives. Ed. Francesca Stella, et al. New York: Routledge, 2016. 17-36. Print.

Trapp, Erin. "The Enemy Combatant as Poet: The Politics of Writing in Poems from Guantanamo." Postmodern Culture 21.3 (2011): http://muse.jhu.edu/article/475119. Print.

Turda, Marius. Modernism and Eugenics. 2016 Vol. London: Palgrave Macmillan, 2010. Print.

Weber, Elisabeth. "Literary Justice?: Poems from Guantanamo Bay Prison Camp." Comparative Literature Studies 48.3 (2011): 417-34. Print.

Zeyas, Alfred D. "Human Rights and Indefinite Detention." International Review of the Red Cross 87.857 (2005): 15-38. Print. 